\title{
Effects of a Moderately Lower Temperature on the Proliferation and Degranulation of Rat Mast Cells
}

\author{
Ruoyu Wang, ${ }^{1,2}$ Xiaoqin Yin, ${ }^{1,2}$ Hui Zhang, ${ }^{1,2}$ Jiwei Wang, ${ }^{1,2}$ Lin Chen, ${ }^{1,2}$ Jingwen Chen, \\ Xiaodong Han, ${ }^{1,2}$ Zou Xiang, ${ }^{3}$ and Dongmei $\mathrm{Li}^{1,2}$ \\ ${ }^{1}$ Immunology and Reproduction Biology Laboratory and State Key Laboratory of Analytical Chemistry for Life Science, \\ Medical School, Nanjing University, Nanjing, Jiangsu 210093, China \\ ${ }^{2}$ Jiangsu Key Laboratory of Molecular Medicine, Nanjing University, Nanjing, Jiangsu 210093, China \\ ${ }^{3}$ Department of Microbiology and Immunology, Mucosal Immunobiology and Vaccine Research Center, \\ Institute of Biomedicine, University of Gothenburg, 40530 Gothenburg, Sweden
}

Correspondence should be addressed to Dongmei Li; lidm@nju.edu.cn

Received 18 January 2016; Accepted 28 March 2016

Academic Editor: Ghislain Opdenakker

Copyright (C) 2016 Ruoyu Wang et al. This is an open access article distributed under the Creative Commons Attribution License, which permits unrestricted use, distribution, and reproduction in any medium, provided the original work is properly cited.

Mast cells are traditionally considered as key effector cells in IgE-mediated allergic diseases. However, the roles of mast cells have also been implicated in diverse physiological and pathological processes. Mast cells are distributed in various organs and tissues of various species. Some of the organs and tissues, such as testis, skin, and the upper part of the respiratory tract, have a temperature that is lower than the body's core temperature. The purpose of the present study was to investigate the effects of a lower temperature on the proliferation and degranulation of rat mast cells. Here, we demonstrate that cell growth was retarded at $35^{\circ} \mathrm{C}$ compared to $37^{\circ} \mathrm{C}$ for both rat peritoneal mast cells (RPMC) and RBL-2H3, a rat mast cell line. Furthermore, RPMC became more susceptible to degranulation at $35^{\circ} \mathrm{C}$ compared to $37^{\circ} \mathrm{C}$. In contrast, degranulation of RBL-2H3 was not as sensitive to temperature change as RPMC. The functionality of mast cells in unique organs with a lower temperature warrants further analysis.

\section{Introduction}

Mast cells are derived from $\mathrm{CD} 34^{+}$pluripotent hematopoietic stem cells $[1,2]$ and they are normal components of connective tissues and are widespread in the organs and tissues of various species [3, 4]. Mast cells are viewed as multifunctional immune cells nowadays despite their well-established role in IgE-mediated allergic pathology [5, 6]. The roles of mast cells are typically elaborated through their release of immune regulatory mediators packed in mast cell granules in the cytoplasm. Upon activation, mast cells can rapidly release granule-associated mediators such as histamine, $\beta$ hexosaminidase, serotonin, and heparin and synthesize and secrete prostaglandin, leukotriene, various cytokines, and chemokines and biologically active substances that play profound roles in both health and disease $[7,8]$. One of the well characterized mechanisms of mast cell activation is through cross-linking of the high affinity IgE receptor, FceRI, on the cell surface by IgE and multivalent allergens. However, mast cells can also respond to FcERI-independent stimuli that include chemicals such as compound 48/80 (c48/80), IgG immune complexes (via $\mathrm{F} c \gamma$ receptors expressed on mast cells), cytokines, chemokines, and even physical stimuli [9, 10].

In recent decades, studies have implicated mast cell functions in various diseases, such as atherosclerosis [11], pulmonary hypertension [12], infertility [13], autoimmunity [14], bladder pain syndrome (interstitial cystitis) [15], anxiety disorders [16], and obesity and diabetes [17]. Mast cells may play critical roles in these pathologies as a result of their localization in almost all the tissues of the body, with a particularly high density in tissues facing an external environment, such as the skin, the airways, and the gastrointestinal tract $[3,18]$. Mast cells also exist in testis, and many studies showed that there is a certain relationship between male infertility and testicular mast cells [13]. Some of these organs 
and tissues, such as testis, skin, and respiratory tract, have a lower temperature than the core body temperature [19]. For example, the skin temperature is $34^{\circ} \mathrm{C}$; the airways have temperatures between $34^{\circ} \mathrm{C}$ and $37^{\circ} \mathrm{C}$; and the testicular temperature is about $35^{\circ} \mathrm{C}$. In view of this, we asked the question whether a lower temperature would have any impact on mast cell proliferation and degranulation. In other words, it would be intriguing to investigate whether mast cells can adapt, temperature-wise, to the local environment.

In the current study, we aimed to investigate the effects of a modestly lower temperature $\left(35^{\circ} \mathrm{C}\right)$ on the proliferation and degranulation of mast cells isolated from rat peritoneum, that is, rat peritoneal mast cells (RPMC), compared with normal core body temperature of $37^{\circ} \mathrm{C}$. We also compared the responsiveness to these two different temperatures between RPMC and the RBL-2H3 cells, a cell line that has been widely used to study the function of mast cells in vitro.

\section{Materials and Methods}

2.1. Ethics Statement. The animal experiments were performed according to the Guide for the Care and Use of Laboratory Animals (The Ministry of Science and Technology of China, 2006) and all experimental protocols were approved under the animal protocol number SYXK (Su) 2009-0017 by the Animal Care and Use Committee of Nanjing University.

2.2. Chemicals and Reagents. RPMI 1640 medium, Minimum Essential Medium (MEM), newborn calf serum, trypsin, collagenase I, and HEPES were purchased from Gibco (Thermo Fisher Scientific, Carlsbad, CA, USA). 4-Nitrophenyl Nacetyl- $\beta$-D-glucosaminide, compound 48/80 (c48/80), cromolyn sodium salt, penicillin, streptomycin sulfate, and trypsin were purchased from Sigma-Aldrich (St. Louis, MO, USA). Cell Counting Kit-8 was obtained from Dojindo Lab (Kumamoto, Japan). Histamine ELISA kit was purchased from IBL International (Hamburg, Germany). The CytoTox$\mathrm{ONE}^{\mathrm{TM}}$ Homogeneous Membrane Integrity Assay kit was purchased from Promega (Madison, WI, USA). Percoll was purchased from Pharmacia (Stockholm, Sweden). Toluidine blue, glycine, and Triton X-100 were purchased from Sunshine Biotechnology Co. Ltd. (Nanjing, China). FITC-labeled rat $\mathrm{mAb}$ to $\mathrm{c}$-Kit was purchased from Abcam (Cambridge, MA, USA). Goat anti-rat IgE polyclonal antibody was purchased from GeneTex Inc. (Irvine, CA, USA). Purified rat IgE was purchased from Life Technologies (Thermo Fisher Scientific, Carlsbad, CA, USA).

2.3. Purification of RPMC. RPMC were purified from peritoneal cells of male Sprague-Dawley rats (220-250 g) obtained from Shanghai Super-B\&K Laboratory Animal Corp. Ltd. by Percoll density gradient centrifugation as described previously [20]. Briefly, rats were sacrificed and disinfected in alcohol followed by an intraperitoneal injection of $15 \mathrm{~mL}$ RPMI1640 and gentle kneading of the abdominal region for $90 \mathrm{~s}$. Next, peritoneal lavage was collected and centrifuged $\left(500 \times \mathrm{g}, 10 \mathrm{~min}\right.$, at $\left.4^{\circ} \mathrm{C}\right)$. The supernatant was discarded and the cells were collected and resuspended in $1 \mathrm{~mL}$ PBS. Cell suspensions were next filtered through a 200-mesh sieve followed by centrifugation at $150 \mathrm{~g}$ for $10 \mathrm{~min}$ at $4^{\circ} \mathrm{C}$, and the pellet was resuspended in PBS. Four milliliters of 90\% Percoll was added. After agitation by swirling, $1 \mathrm{~mL}$ PBS was dropped in slowly. The mixture was centrifuged $(150 \times \mathrm{g})$ for $6 \mathrm{~min}$. The cells were collected and washed three times with PBS. Approximately $1-5 \times 10^{5}$ cells were obtainable from each rat. Purified RPMC were suspended in RPMI 1640 containing $10 \% \mathrm{FBS}, 100 \mathrm{IU} / \mathrm{mL}$ penicillin, and $100 \mathrm{IU} / \mathrm{mL}$ streptomycin. Cells were incubated in a humidified atmosphere of $95 \%$ air, $5 \% \mathrm{CO}_{2}$. The purity of mast cells was confirmed by toluidine blue staining and flow cytometry gating on the c-Kit positive population.

2.4. $\mathrm{RBL}-2 \mathrm{H} 3 \mathrm{Culture}$. RBL-2H3 was purchased from China Center for Type Culture Collection (CCTCC) and seeded into $100 \mathrm{~mm}$ culture dishes at a density of approximately $2 \times 10^{5}$ cells per dish in MEM medium containing $10 \%$ FBS, $0.11 \mathrm{~g} / \mathrm{L}$ sodium pyruvate, $1.5 \mathrm{~g} / \mathrm{L} \mathrm{NaHCO}_{3}, 100 \mathrm{IU} / \mathrm{mL}$ penicillin, and $100 \mathrm{IU} / \mathrm{mL}$ streptomycin. Cells were incubated in a humidified atmosphere of $95 \%$ air, $5 \% \mathrm{CO}_{2}$. Cells were passaged using trypsin upon reaching $80 \%-90 \%$ confluence and were plated at $2.0 \times 10^{5}$ cells $/ \mathrm{mL}$ in 24 - or 6 -well plates for the experiments outlined below.

2.5. Cell Proliferation Assay. Cell proliferation was determined by the Cell Counting Kit-8 (CCK-8) method. CCK-8 contains WST- 8 which can be deoxidized to a hydrosoluble formazan dye by mitochondrial dehydrogenase in living cells. Briefly, purified RPMC or RBL-2H3 cells were washed once and plated into 96 -well plates at a cell density of $2 \times$ $10^{5}$ cells/mL $(100 \mu \mathrm{L} /$ well). Next, cells were incubated in a humidified atmosphere of $95 \%$ air, $5 \% \mathrm{CO}_{2}$, at $35^{\circ} \mathrm{C}$ or $37^{\circ} \mathrm{C}$. After incubation for various time periods as indicated, the cell culture plates were centrifuged and the supernatant was discarded. Serum-free medium that contained CCK8 was added to each well ( $100 \mu \mathrm{L} /$ well) followed by a further incubation at $35^{\circ} \mathrm{C}$ or $37^{\circ} \mathrm{C}$ for $4 \mathrm{~h}$. The absorbance was measured on an automated microplate reader (Bio-Rad, Japan) at $450 \mathrm{~nm}$. This assay was repeated at least three times in sextuplicate.

2.6. Mast Cell Activation. RPMC and RBL-2H3 were activated by either IgE or c48/80 in 24 -well plates $\left(2.0 \times 10^{5}\right.$ cells $/ \mathrm{mL}, 500 \mu \mathrm{L} /$ well). For IgE-mediated activation, mast cells were incubated with purified rat $\operatorname{IgE}(1 \mu \mathrm{g} / \mathrm{mL})$ for $1 \mathrm{~h}$ followed by two washes with PBS. Next, cells were incubated in serum-free medium containing $5 \mu \mathrm{g} / \mathrm{mL}$ anti-rat $\operatorname{IgE}$ for $30 \mathrm{~min}$. Alternatively, mast cells were incubated in serumfree medium containing $20 \mu \mathrm{g} / \mathrm{mL} \mathrm{c} 48 / 80$ for $30 \mathrm{~min}$. In some experiments, cromolyn sodium $(10 \mu \mathrm{mol} / \mathrm{L})$ was added 10 min before stimulation.

2.7. $\beta$-Hexosaminidase Release Measurement. $\beta$-Hexosaminidase release was assayed according to a previously published method [21]. Briefly, $50 \mu \mathrm{L}$ supernatant from cells that were appropriately activated was transferred to a 96-well plate and mixed with $50 \mu \mathrm{L}$ substrate solution followed by incubation for $2 \mathrm{~h}$ at $37^{\circ} \mathrm{C}$. Glycine $(0.2 \mathrm{M}, \mathrm{pH} 10)$ was added to each well to stop the reaction. The absorbance (OD) at $405 \mathrm{~nm}$ was measured with an automated microplate reader (Bio-Rad). 


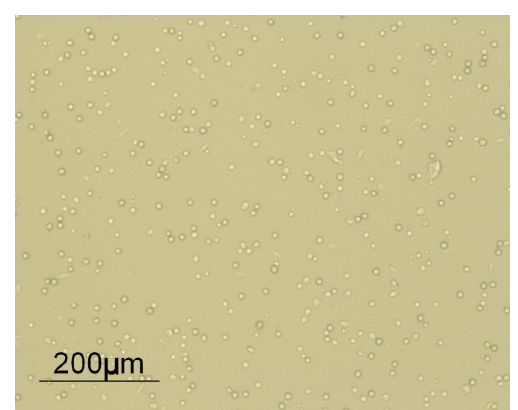

(a)

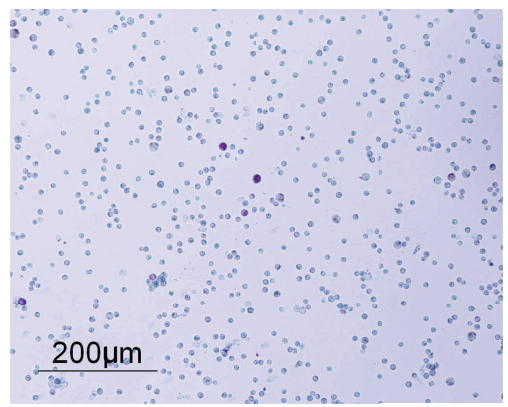

(d)

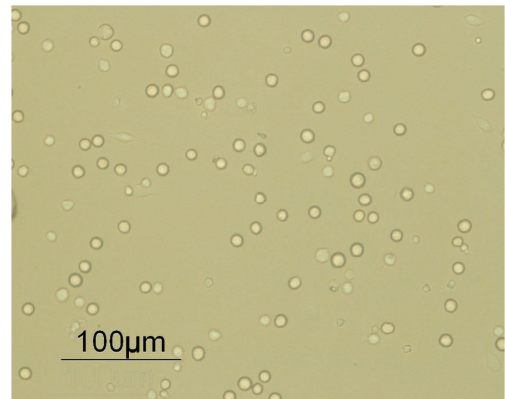

(b)

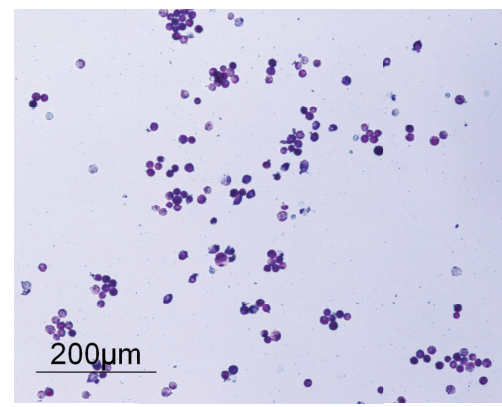

(e)

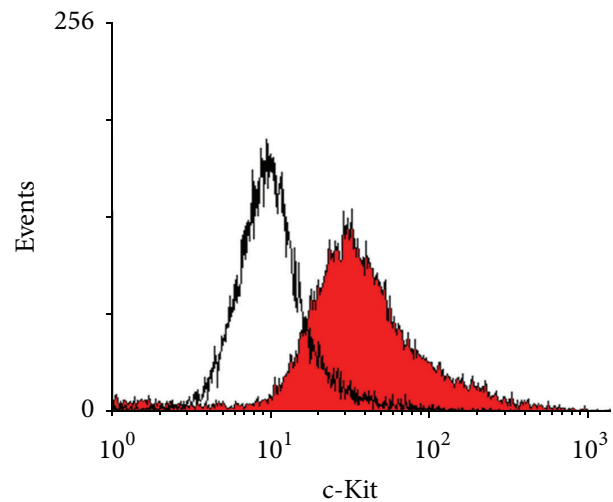

(c)

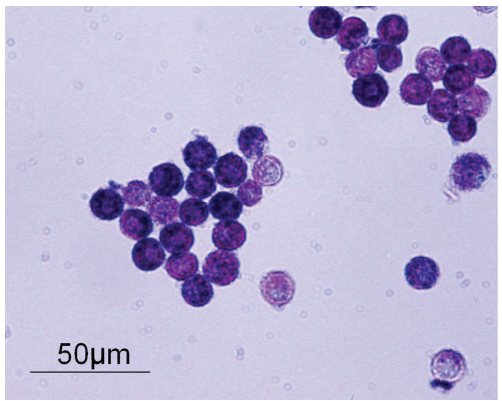

(f)

Figure 1: Purification of rat peritoneal mast cells. ((a) and (b)) Purified rat peritoneal mast cells were examined by phase-contrast microscopy at different magnification rates. (c) c-Kit expression by peritoneal cells before (line) and after (solid) purification was carried out by flow cytometric analysis. ((d)-(f)) Rat peritoneal cells either unpurified (d) or following purification ((e) and (f)) were stained with toluidine blue and examined by microscopy.

To determine total release of mast cell granule-associated $\beta$ hexosaminidase $\left(\mathrm{OD}_{\text {total }}\right)$, cells were treated with $0.1 \%(\mathrm{v} / \mathrm{v})$ Triton $\mathrm{X}-100$. The release rate was determined as follows: release $(\%)=\left(\mathrm{OD}_{\mathrm{eg}}-\mathrm{OD}_{\mathrm{bc}}\right) /\left(\mathrm{OD}_{\text {total }}-\mathrm{OD}_{\mathrm{bc}}\right)$, where $\mathrm{OD}_{\mathrm{eg}}$ and $\mathrm{OD}_{\mathrm{bc}}$ represent the absorbance of the experimental group and blank control, respectively. The measurement was repeated at least three times in quadruplicate.

2.8. Measurement of Histamine Release. Histamine release was determined using a histamine ELISA kit from IBL International (Hamburg, Germany) [22]. After activation, cells were placed on ice for about $10 \mathrm{~min}$ followed by centrifugation at $500 \mathrm{~g}$ for $10 \mathrm{~min}$. Supernatants were collected for measuring histamine content. The concentration of the fluorescent product formed during the reaction, which correlates to the histamine concentration, was measured using a fluorescence microplate reader set at $\lambda_{\mathrm{ex}}=349 \mathrm{~nm}$ and $\lambda_{\mathrm{em}}=448 \mathrm{~nm}$. Total cellular release of histamine $\left(C_{\text {total }}\right)$ was achieved by treatment with $0.1 \%(\mathrm{v} / \mathrm{v})$ Triton $\mathrm{X}-100$. The release rate was determined as follows: release (\%) = $\left(C_{\text {eg }}-C_{\mathrm{bc}}\right) /\left(C_{\text {total }}-C_{\mathrm{bc}}\right)$, where $C_{\text {eg }}$ and $C_{\mathrm{bc}}$ represent the concentrations of the experimental group and blank control, respectively. The measurement was repeated at least three times in quadruplicate.
2.9. Statistics. The results are expressed as means \pm SE. Statistical evaluation of the data was performed by unpaired Student's $t$-test for comparisons between two groups and by ANOVA followed by Dunnett's test for comparisons between more than two groups. A value of $P<0.05$ was regarded as significant.

\section{Results}

3.1. Culture Temperature Modulates Mast Cell Proliferation. RPMC were obtained and purified by Percoll density gradient centrifugation [23]. Following purification, mast cell morphology was examined by microscopy (Figures 1(a) and 1(b)). About $87 \%$ of the purified peritoneal mast cells expressed the mast cell marker c-Kit confirmed by flow cytometry, compared with the low frequency of c-Kit-expressing cells before purification (Figure 1(c)). The purity of RPMC reached greater than $90 \%$ by toluidine blue staining (Figures 1(e) and $1(\mathrm{f})$ ) in contrast to the low frequency before purification (Figure $1(\mathrm{~d})$ ). Almost all the RBL-2H3 cells expressed c-Kit (Figure 2).

Some of the RPMC and RBL-2H3 cells were cultured at $35^{\circ} \mathrm{C}$ instead of $37^{\circ} \mathrm{C}$ to simulate the lower temperature at body surface locations. RPMC did not show signs of 


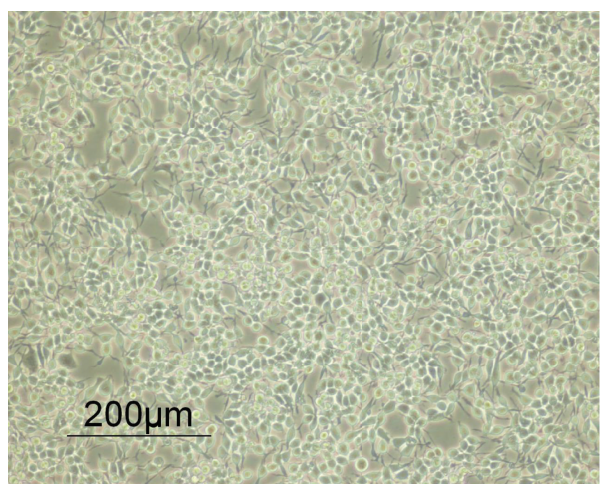

(a)

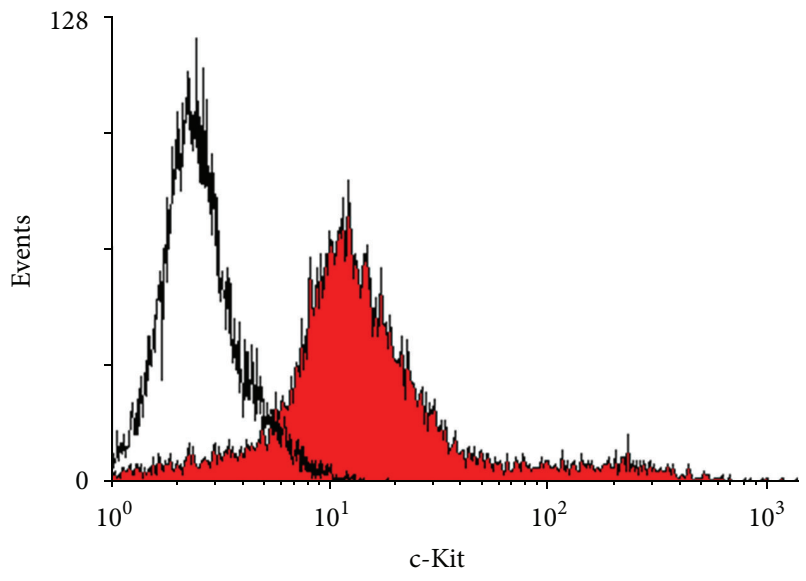

(b)

FIGURE 2: Purity analysis of RBL-2H3. (a) The morphology of RBL-2H3 cells was examined by phase-contrast photomicrography. (b) Cellular expression of c-Kit was analyzed by flow cytometric analysis. Line, isotype antibody control; solid, anti-c-Kit antibody.

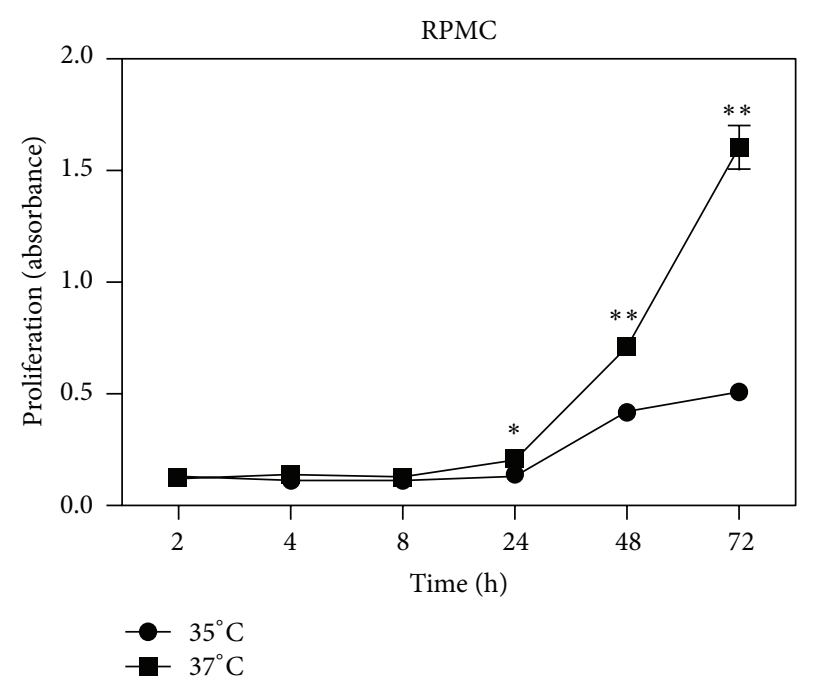

(a)

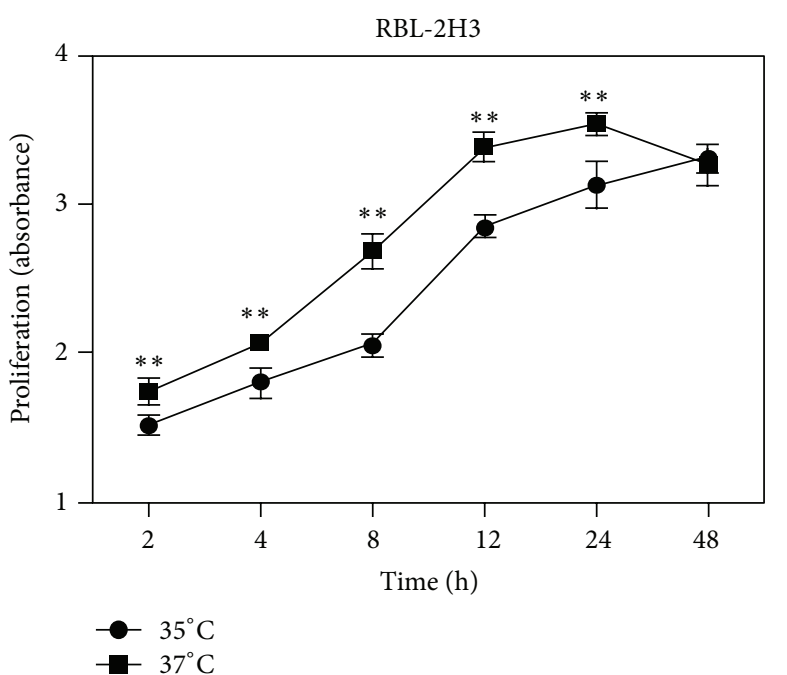

(b)

FIGURE 3: Growth curve of mast cells under different culture temperatures. Rat peritoneal mast cells (RPMC) (a) and RBL-2H3 (b) were cultured at $35^{\circ} \mathrm{C}$ or $37^{\circ} \mathrm{C}$ as indicated and cell proliferation was recorded. Data are expressed as the means \pm SE $(n=6)$, representing at least three separate experiments. ${ }^{*} P<0.05 ;{ }^{* *} P<0.01$, compared between the two groups at the same time point.

proliferation until about $24 \mathrm{~h}$ after culture. After that, the proliferation of RPMC cultured at $35^{\circ} \mathrm{C}$ was significantly weaker than that at $37^{\circ} \mathrm{C}$. Proliferation inhibition became more pronounced with an extended exposure time (Figure 3(a)). For RBL-2H3, growth inhibition as a result of low temperature culture was sustained from $2 \mathrm{~h}$ through $24 \mathrm{~h}$ (Figure 3(b)).

3.2. Degranulation of RPMC Is Modulated by Culture Temperature. Release of $\beta$-hexosaminidase and histamine is commonly used as readouts of mast cell degranulation. No significant difference in the basal release of $\beta$-hexosaminidase was observed when RPMC were cultured either at $35^{\circ} \mathrm{C}$ or at $37^{\circ} \mathrm{C}$
(Figure $4(\mathrm{a})$ ). After treatment with $\mathrm{c} 48 / 80$ or IgE/anti-IgE, however, $\beta$-hexosaminidase release was more robust at $35^{\circ} \mathrm{C}$ compared to $37^{\circ} \mathrm{C}$ (Figure 4(a)). Histamine release profile was largely similar to that of $\beta$-hexosaminidase. For histamine release by RPMC, both spontaneous and stimulated release triggered by $c 48 / 80$ or IgE cross-linking were greater at $35^{\circ} \mathrm{C}$ compared to $37^{\circ} \mathrm{C}$ (Figure $4(\mathrm{~b})$ ). The clinically widely used mast cell stabilizer, cromolyn sodium, exerted differential effects in our assay system. For $\beta$-hexosaminidase release, cromolyn failed to suppress c48/80-mediated degranulation either at $35^{\circ} \mathrm{C}$ or at $37^{\circ} \mathrm{C}$. However, this inhibitor could partially inhibit IgE-mediated release of $\beta$-hexosaminidase at $35^{\circ} \mathrm{C}$ but not at $37^{\circ} \mathrm{C}$ (Figure $4(\mathrm{a})$ ). For histamine release, 


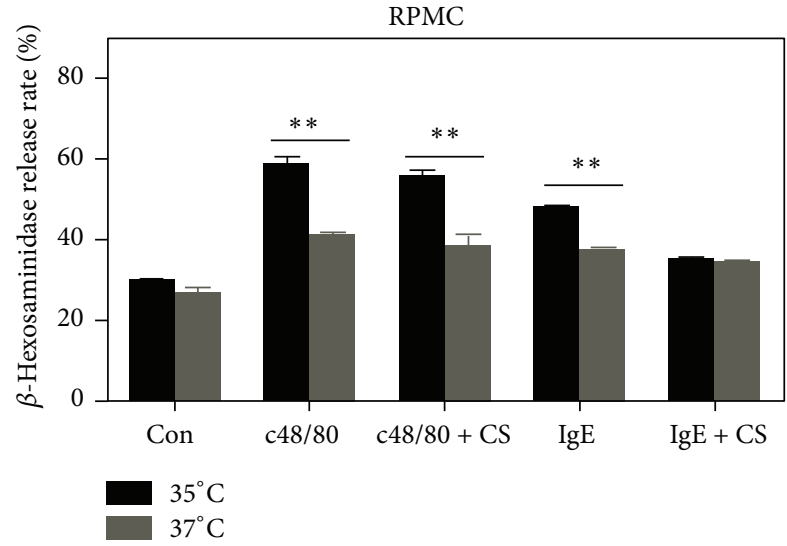

(a)

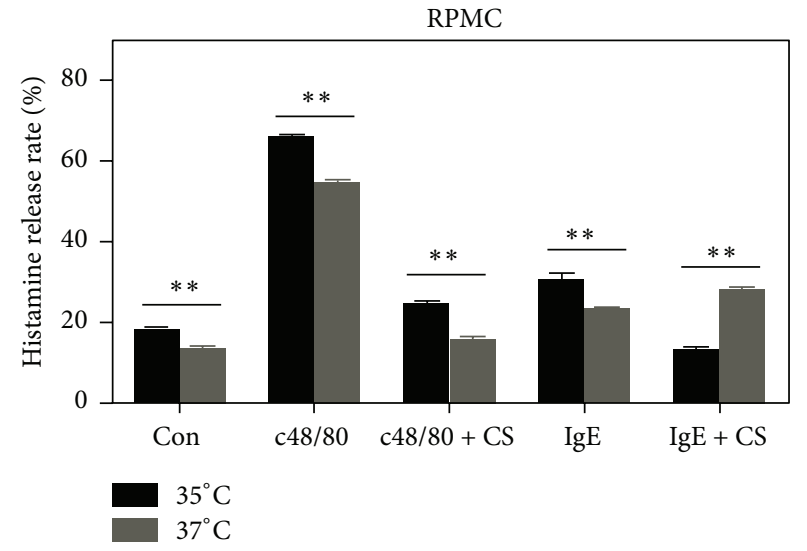

(b)

FIGURE 4: The effect of temperature on rat peritoneal mast cell degranulation. Rat peritoneal mast cells (RPMC) were left untreated (Con) or treated by either $c 48 / 80$ or a combination of $\operatorname{IgE}$ and anti-IgE (IgE). In some experiments, cells were activated in the presence of the mast cell stabilizer cromolyn sodium (CS). $\beta$-Hexosaminidase (a) and histamine (b) release was measured. $\beta$-Hexosaminidase or histamine release is expressed as percent of the total (the means $\pm \mathrm{SE}, n=4$, representing at least three separate experiments). ${ }^{* *} P<0.01$.

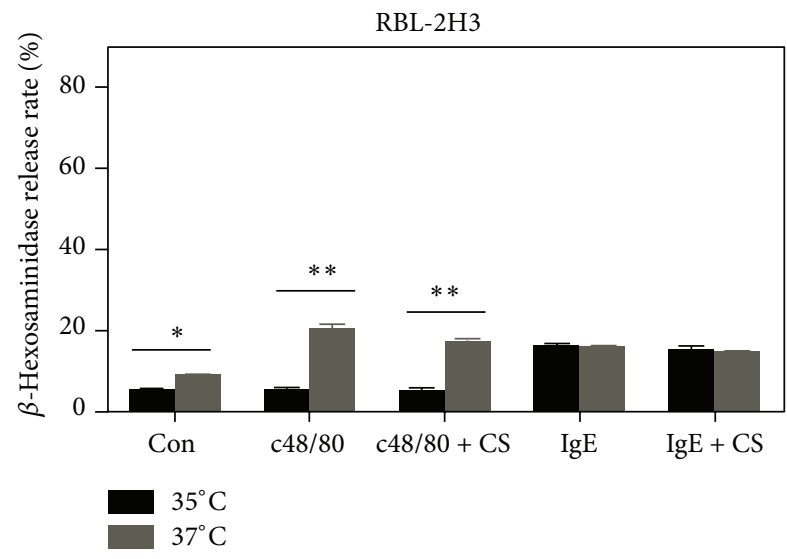

(a)

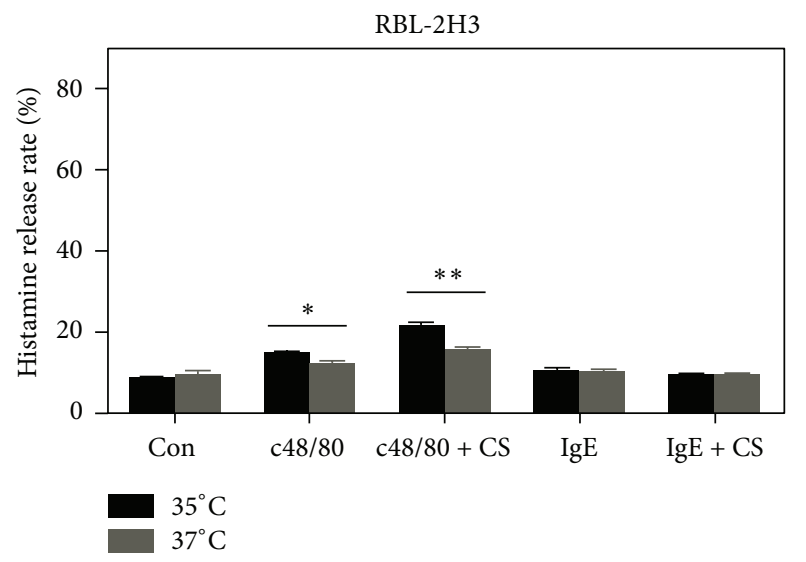

(b)

FIGURE 5: The effect of temperature on RBL-2H3 degranulation. RBL-2H3 cells were left untreated (Con) or treated by either c48/80 or a combination of IgE and anti-IgE. In some experiments, cells were activated in the presence of the mast cell stabilizer cromolyn sodium (CS). $\beta$-Hexosaminidase (a) and histamine (b) release was measured. $\beta$-Hexosaminidase or histamine release is expressed as percent of the total (the means $\pm \mathrm{SE}, n=4$, representing at least three separate experiments). ${ }^{*} P<0.05$; ${ }^{* *} P<0.01$.

cromolyn could substantially inhibit c48/80-mediated release at both temperatures. In contrast, cromolyn-mediated inhibition of degranulation triggered by IgE cross-linking was efficient at $35^{\circ} \mathrm{C}$ but not at $37^{\circ} \mathrm{C}$ (Figure $4($ b) ).

3.3. The Degranulation of RBL-2H3 Cells Is Modulated by Culture Temperature. Both basal $\beta$-hexosaminidase release and the release induced by $c 48 / 80$ at $37^{\circ} \mathrm{C}$ were remarkably higher than those at $35^{\circ} \mathrm{C}$. In contrast, $\beta$-hexosaminidase release as a result of cross-linking of FceRI by IgE reached similar levels at both $35^{\circ} \mathrm{C}$ and $37^{\circ} \mathrm{C}$ (Figure 5(a)). Slightly higher histamine release induced by $c 48 / 80$ was observed at $35^{\circ} \mathrm{C}$ compared to $37^{\circ} \mathrm{C}$ (Figure 5(b)). IgE was not able to activate RBL-2H3 for pronounced histamine release (Figure 5(b)). Cromolyn failed to inhibit degranulation of RBL-2H3 cells (Figure 5).

\section{Discussion}

The effects of temperature on the functionality of mast cells have been previously explored [24-27], and the possible clinical implications in this regard have also been investigated [28]. However, these studies addressed drastically changed temperatures, for example, more than $10^{\circ} \mathrm{C}$ lower than the core body temperature of $37^{\circ} \mathrm{C}$. In order to investigate the effect of a modestly lower temperature on mast cell functionality, we cultured RPMC and RBL-2H3 cells at 
$35^{\circ} \mathrm{C}$ and compared their performance with that of cells at $37^{\circ} \mathrm{C}$.

Despite the fact that mast cell proliferation in vitro was slightly, but consistently, inhibited at $35^{\circ} \mathrm{C}$ over a broad range of time points, this may not necessarily affect in vivo mast cell physiology as terminally differentiated, tissue resident mast cells do not proliferate vigorously.

For RPMC degranulation triggered either by IgE receptor cross-linking or by $c 48 / 80$, release of $\beta$-hexosaminidase and histamine was enhanced as a result of incubation at $35^{\circ} \mathrm{C}$. Thus, we may speculate that peritoneal mast cells which are used to a core body temperature of $37^{\circ} \mathrm{C}$ could be more sensitive to external stimuli upon exposure to a lower temperature. In contrast, a lower incubation temperature differentially impacted RBL-2H3 cell line with regard to specific granule products. For histamine release, $c 48 / 80$ induced a higher level of degranulation at $35^{\circ} \mathrm{C}$ compared with $37^{\circ} \mathrm{C}$. However, the pattern was reversed for $\beta$-hexosaminidase release. This is possible as different granule products may be packaged in distinct granules which are not released upon a triggering stimulus at the same pace [29]. Cromolyn sodium is used as a stabilizer suppressing mast cell activation [30]. We did not observe its inhibitory effect on RBL-2H3 cells at all the conditions we tested. For RPMC activation, the effect of cromolyn sodium was also stimulus-specific and temperature-specific. The effectiveness of cromolyn sodium for topical application against skin allergies is reportedly controversial [31, 32]. Therefore, it would be interesting to investigate the property of cromolyn for inhibiting human mast cell degranulation at a lower temperature.

RBL-2H3 cells were originally isolated and cloned from Wistar rat basophilic leukemia cells [33]. These cells have high affinity IgE receptors, and they have been used extensively to study FceRI-dependent activation pathways [34]. Here, we revealed certain differences between RBL-2H3 and ex vivo RPMC, as pointed out also by others [35].

\section{Conclusions}

In this study, we explored the effects of a modestly lower temperature on the proliferation and degranulation of RPMC as well as the rat mast cell line RBL-2H3, which may provide implications for both physiological and pathological functions of mast cells in certain tissues exposed to a lower temperature.

\section{Disclosure}

Zou Xiang and Dongmei Li share senior authorship.

\section{Competing Interests}

The authors declare no competing interests regarding the publication of this paper.

\section{Authors' Contributions}

Ruoyu Wang and Xiaoqin Yin contributed equally to this work. Dongmei Li, Zou Xiang, and Xiaodong Han contributed to conception and design of the experiments. Ruoyu
Wang, Dongmei Li, Xiaoqin Yin, Zou Xiang, Hui Zhang, Jiwei Wang, Lin Chen, and Jingwen Chen contributed to collection, analysis, and interpretation of data. Zou Xiang and Dongmei Li contributed to drafting the paper or revising it critically for important intellectual content. All authors have approved the paper.

\section{Acknowledgments}

This work was supported by National Natural Science Foundation of China (21377052, 31370524, and 81570059), Doctoral Program of Higher Education (SRFDP), Ministry of Education, China (20130091110050), and Natural Science Foundation of Jiangsu Province of China (BK20131281 and BK20151398).

\section{References}

[1] A. S. Kirshenbaum, S. W. Kessler, J. P. Goff, and D. D. Metcalfe, "Demonstration of the origin of human mast cells from CD34+ bone marrow progenitor cells," The Journal of Immunology, vol. 146, no. 5, pp. 1410-1415, 1991.

[2] M. F. Gurish and J. A. Boyce, "Mast cells: ontogeny, homing, and recruitment of a unique innate effector cell," The Journal of Allergy and Clinical Immunology, vol. 117, no. 6, pp. 1285-1291, 2006.

[3] S. J. Collington, T. J. Williams, and C. L. Weller, "Mechanisms underlying the localisation of mast cells in tissues," Trends in Immunology, vol. 32, no. 10, pp. 478-485, 2011.

[4] C. Gersch, O. Dewald, M. Zoerlein, L. H. Michael, M. L. Entman, and N. G. Frangogiannis, "Mast cells and macrophages in normal C57/BL/6 mice," Histochemistry and Cell Biology, vol. 118, no. 1, pp. 41-49, 2002.

[5] J. Kalesnikoff and S. J. Galli, "New developments in mast cell biology," Nature Immunology, vol. 9, no. 11, pp. 1215-1223, 2008.

[6] A. L. St John and S. N. Abraham, "Innate immunity and its regulation by mast cells," Journal of Immunology, vol. 190, no. 9, pp. 4458-4463, 2013.

[7] R. Sagi-Eisenberg, "The mast cell: where endocytosis and regulated exocytosis meet," Immunological Reviews, vol. 217, no. 1, pp. 292-303, 2007.

[8] S. J. Galli, J. Kalesnikoff, M. A. Grimbaldeston, A. M. Piliponsky, C. M. M. Williams, and M. Tsai, "Mast cells as 'tunable' effector and immunoregulatory cells: recent advances," Annual Review of Immunology, vol. 23, pp. 749-786, 2005.

[9] M. Metz and M. Maurer, "Mast cells-key effector cells in immune responses," Trends in Immunology, vol. 28, no. 5, pp. 234-241, 2007.

[10] S. J. Galli and M. Tsai, "Mast cells: versatile regulators of inflammation, tissue remodeling, host defense and homeostasis," Journal of Dermatological Science, vol. 49, no. 1, pp. 7-19, 2008.

[11] I. Bot, G.-P. Shi, and P. T. Kovanen, "Mast cells as effectors in atherosclerosis," Arteriosclerosis, Thrombosis, and Vascular Biology, vol. 35, no. 2, pp. 265-271, 2015.

[12] H. Maxová, J. Herget, and M. Vízek, "Lung mast cells and hypoxic pulmonary hypertension," Physiological Research, vol. 61, no. 1, pp. 1-11, 2012.

[13] G. Haidl, Y.-G. Duan, S.-J. Chen, F.-M. Kohn, H.-C. Schuppe, and J.-P. Allam, "The role of mast cells in male infertility," Expert Review of Clinical Immunology, vol. 7, no. 5, pp. 627-634, 2011. 
[14] F. Bicer, C. Z. Altuntas, K. Izgi et al., "Chronic pelvic allodynia is mediated by CCL2 through mast cells in an experimental autoimmune cystitis model," American Journal of PhysiologyRenal Physiology, vol. 308, no. 2, pp. F103-F113, 2015.

[15] F. Ercan, T. Şan, and S. Çavdar, "The effects of cold-restraint stress on urinary bladder wall compared with interstitial cystitis morphology," Urological Research, vol. 27, no. 6, pp. 454-461, 1999.

[16] Y. Ikarashi and M. Yuzurihara, "Experimental anxiety induced by histaminergics in mast cell-deficient and congenitally normal mice," Pharmacology Biochemistry and Behavior, vol. 72, no. 1-2, pp. 437-441, 2002.

[17] J. Wang and G.-P. Shi, "Mast cell stabilization: novel medication for obesity and diabetes," Diabetes/Metabolism Research and Reviews, vol. 27, no. 8, pp. 919-924, 2011.

[18] H. Vliagoftis and A. D. Befus, "Rapidly changing perspectives about mast cells at mucosal surfaces," Immunological Reviews, vol. 206, pp. 190-203, 2005.

[19] R. Niedermann, E. Wyss, S. Annaheim, A. Psikuta, S. Davey, and R. M. Rossi, "Prediction of human core body temperature using non-invasive measurement methods", International Journal of Biometeorology, vol. 58, no. 1, pp. 7-15, 2014.

[20] T. Suzuki-Nishimura, K. Nagaya, K. Matsuda et al., "Sugarspecific inhibitory effects of wheat germ agglutinin and phytohemagglutinin-E4 on histamine release induced by basic secretagogues from rat peritoneal mast cells and their possible action sites," Japanese Journal of Pharmacology, vol. 57, no. 1, pp. 79-90, 1991.

[21] M. Kobayashi, H. Matsushita, K. Yoshida, R.-I. Tsukiyama, T. Sugimura, and K. Yamamoto, "In vitro and in vivo anti-allergic activity of soy sauce," International Journal of Molecular Medicine, vol. 14, no. 5, pp. 879-884, 2004.

[22] P. A. Shore, A. Burkhalter, and V. H. Cohn Jr., "A method for the fluorometric assay of histamine in tissues," The Journal of Pharmacology and Experimental Therapeutics, vol. 127, pp. 182186, 1959.

[23] N. W. Brattig, C. E. Medina-De la Garza, and F. W. Tischendorf, "Comparative study of eosinophil purification on Nycodenz, Metrizamide and Percoll density gradients," European Journal of Haematology, vol. 39, no. 2, pp. 148-153, 1987.

[24] E. E. Graevskaya, M. Y. Akhalaya, and E. N. Goncharenko, "Effects of cold stress and epinephrine on degranulation of peritoneal mast cells in rats," Bulletin of Experimental Biology and Medicine, vol. 131, no. 4, pp. 333-335, 2001.

[25] B.-H. Chen, M. A. Kilmon, C. Ma et al., "Temperature effect on IgE binding to CD23 versus FceRI," Journal of Immunology, vol. 170, no. 4, pp. 1839-1845, 2003.

[26] E. Mortaz, F. A. Redegeld, M. W. van der Heijden, H. R. Wong, F. P. Nijkamp, and F. Engels, "Mast cell activation is differentially affected by heat shock," Experimental Hematology, vol. 33, no. 8, pp. 944-952, 2005.

[27] G. V. Trunova, "Morphofunctional characteristic of mast cells in $\mathrm{BALB} / \mathrm{c}$ and $\mathrm{C} 57 \mathrm{Bl} / 6$ mice during cold exposure," Bulletin of Experimental Biology and Medicine, vol. 138, no. 2, pp. 182-184, 2004.

[28] K. Krause, T. Zuberbier, and M. Maurer, "Modern approaches to the diagnosis and treatment of cold contact urticaria," Current Allergy and Asthma Reports, vol. 10, no. 4, pp. 243-249, 2010.

[29] A. Lundequist and G. Pejler, "Biological implications of preformed mast cell mediators," Cellular and Molecular Life Sciences, vol. 68, no. 6, pp. 965-975, 2011.
[30] B. Huang, S. Huang, Y. Chen et al., "Mast cells modulate acute toxoplasmosis in murine models," PLoS ONE, vol. 8, no. 10, Article ID e77327, 2013.

[31] M. G. Pike and D. J. Atherton, "Failure of a new topical sodium cromoglycate formulation to improve atopic dermatitis," European Journal of Pediatrics, vol. 148, no. 2, p. 170, 1988.

[32] R. Stainer, S. Matthews, S. H. Arshad et al., "Efficacy and acceptability of a new topical skin lotion of sodium cromoglicate (Altoderm) in atopic dermatitis in children aged 2-12 years: a double-blind, randomized, placebo-controlled trial," The British Journal of Dermatology, vol. 152, no. 2, pp. 334-341, 2005.

[33] E. Passante and N. Frankish, "The RBL-2H3 cell line: its provenance and suitability as a model for the mast cell," Inflammation Research, vol. 58, no. 11, pp. 737-745, 2009.

[34] R. K. Palmer, L. M. Hutchinson, B. T. Burpee et al., "Antibacterial agent triclosan suppresses RBL-2H3 mast cell function," Toxicology and Applied Pharmacology, vol. 258, no. 1, pp. 99108, 2012.

[35] E. Passante, C. Ehrhardt, H. Sheridan, and N. Frankish, "RBL2H3 cells are an imprecise model for mast cell mediator release," Inflammation Research, vol. 58, no. 9, pp. 611-618, 2009. 


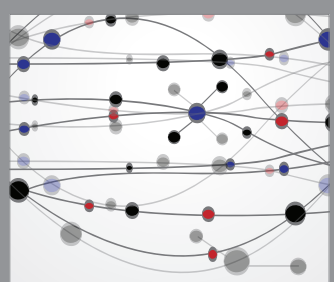

The Scientific World Journal
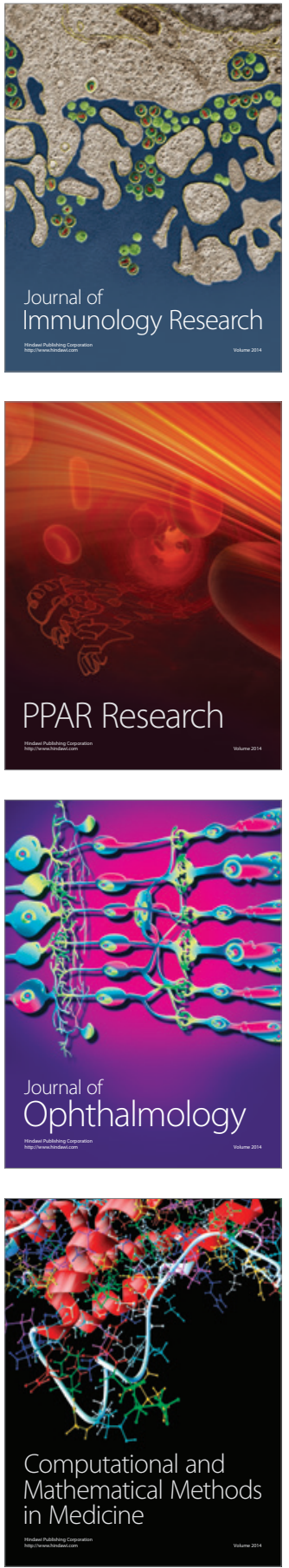

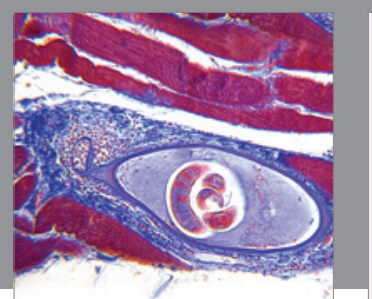

Gastroenterology Research and Practice

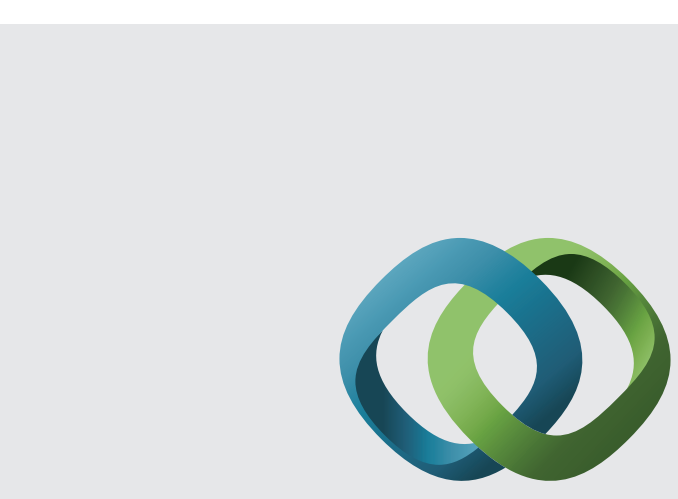

\section{Hindawi}

Submit your manuscripts at

http://www.hindawi.com
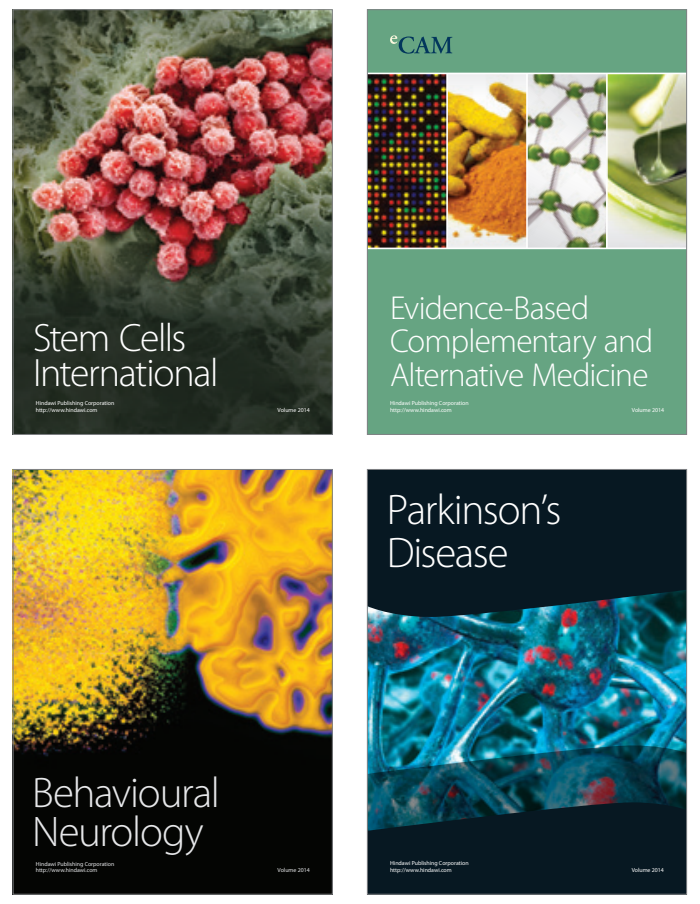
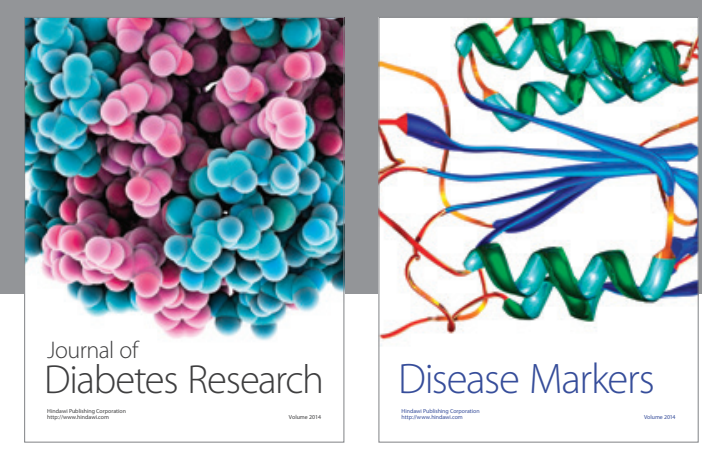

Disease Markers
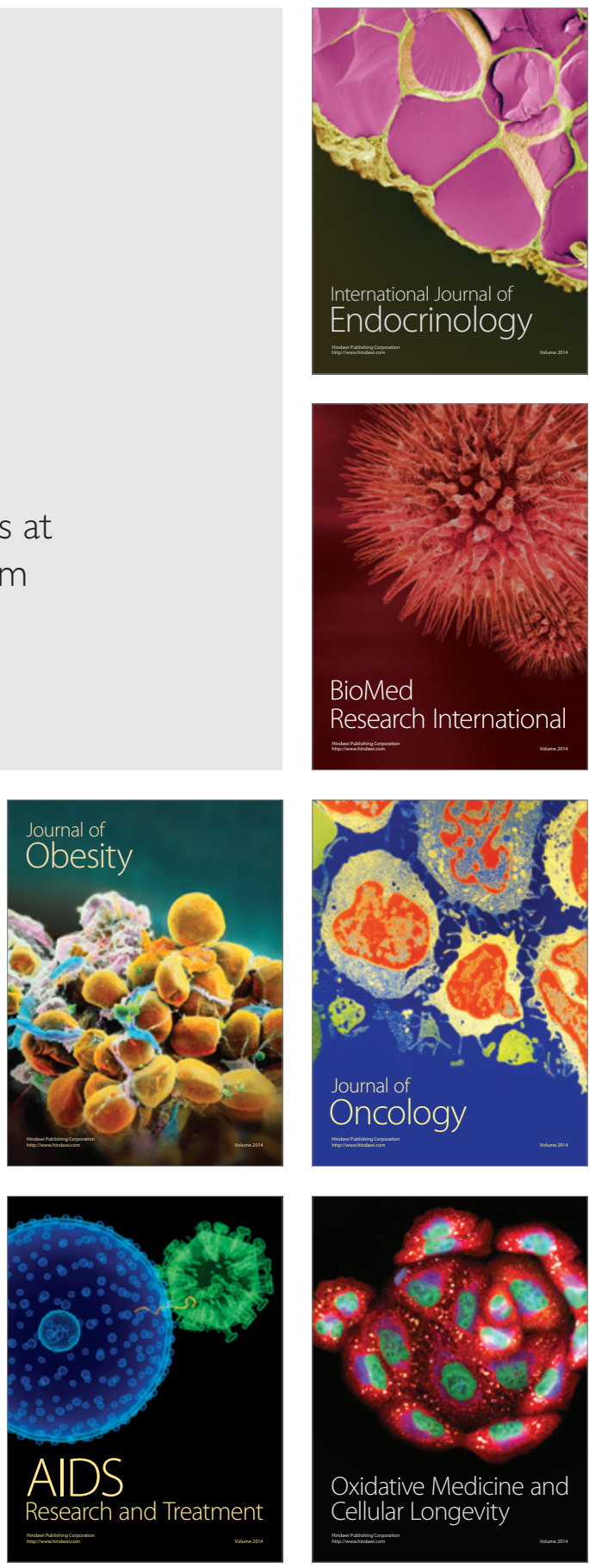